\title{
PENGEMBANGAN KURIKULUM BAHASA ARAB PADA KELAS MATA PELAJARAN DI MTsN SUMBER BUNGUR PAMEKASAN
}

\author{
Achmad Muhlis \\ (STAIN Pamekasan/Madmukhlis@gmail.com)
}

\begin{abstract}
:
One of the Among the breakthroughs of MTs Sumber Bungur Pamekasan as a formal educational institution that is trusted as a pilot school in the area of East Java religious ministry is the realization of the program in the field of Arabic language curriculum development. The purpose of this study was about to describe how the concept and development of the classroom curriculum model in Arabic subject at MTs Sumber Bungur Pamekasan, and what are the factors supporting and hindering the implementation of the curriculum. The research result shows that the class curriculum of Arabic subjects is basically develop the 2006 curriculum which emphasis on the needs of the community and the islamic boarding school. MTs Sumber Bungur Pamekasan develop classroom-based curriculum of the Arabic subjects that later termed as classroom curriculum of Arabic subjects. The Curriculum development model used is the central de-central, the curriculum development process that combines the two approaches, administrative and grass roots approach. Curriculum development is manifested in the additional hours of lessons and teaching materials, namely on subjects PAI and Arabic which was originally only 11 hours of lessons to 24 hours of lessons. The addition of the lesson period is used to examine the science nahwu, shorrof, hermeneutics (tafsir), and other classical holy books. The factors supporting the implementation of curriculum development are: 1) the Motivation by the Regional Office of the Religion Ministry of East Java, 2) the Principals Commitment, 3) Professional competence of the Arabic subjects classroom teachers, 4) The existence of Islamic boarding school sumber bungur as an institution that strengthens the learning process and 5) the students Input who have an initial understanding of the material that will be presented. While the inhibiting factors are: 1) No allocation of special funds, 2) There is inequality in the ability of teachers in curriculum development, 3) the prevalence of the teachers's ability in teaching Arabic, and 4) there are some students who feel bored when learning Arabic because of the many hours of lessons being presented.
\end{abstract}

Keywords:

Curriculum Development, Arabic Language, Classical Curriculum

\section{Pendahuluan}

Undang-Undang Nomor 20 Tahun

2003 tentang Sistem Pendidikan

Nasional Pasal 36 ayat (1) menyatakan

bahwa "Pengembangan kurikulum
dilakukan dengan mengacu pada
standar nasional pendidikan untuk
mewujudkan tujuan pendidikan

OKARA, Vol. 2, Tahun X, Nopember 2015 
nasional," dan ayat (2) menyebutkan bahwa "Kurikulum pada semua jenjang dan jenis pendidikan dikembangkan dengan prinsip diversifikasi sesuai dengan satuan pendidikan, potensi daerah, dan peserta didik". Pasal 38 ayat (2) menyatakan bahwa "Kurikulum pendidikan dasar dan menengah dikembangkan sesuai dengan relevansinya oleh setiap kelompok atau satuan pendidikan dan komite sekolah atau madrasah di bawah koordinasi dan supervisi dinas pendidikan atau kantor Kementerian Agama Kabupaten atau Kota untuk pendidikan dasar dan Provinsi untuk pendidikan menengah ${ }^{1}$.

Dalam rangka melaksanakan perundangan tersebut, telah diterbitkan Peraturan Pemerintah (PP) No.19 Tahun 2005 tentang Standar Nasional Pendidikan yang meliputi delapan standar, yaitu standar isi, standar kompetensi lulusan, standar proses, standar penilaian, standar sarana dan prasarana, standar pengelolaan, standar tenaga kependidikan, dan standar pembiayaan. Pasal 17 (ayat 2) PP tersebut menyatakan bahwa "Sekolah dan komite sekolah, atau madrasah dan komite madrasah, mengembangkan kurikulum tingkat satuan pendidikan dan silabusnya berdasarkan kerangka dasar kurikulum dan standar kompetensi lulusan, di bawah supervisi dinas kabupaten atau kota yang bertanggung

\footnotetext{
${ }^{1}$ Direktorat Jenderal Pendidikan Islam Kementerian Agama, Undang-Undang dan Peraturan Pemerintah RI tentang Pendidikan, (Jakarta: Depag, 2006), hal. 7.
}

jawab di bidang pendidikan untuk SD, SMP, SMA, dan MK, dan Kementerian yang menangani urusan pemerintahan di bidang agama untuk MI, MTs, MA, dan MAK.

Sejak keluarnya PP. No. 19 Tahun 2005 secara resmi penyusunan kurikulum menjadi tanggung jawab setiap satuan pendidikan (sekolah dan madrasah), dengan demikian tidak lagi dikenal istilah kurikulum nasional yang dulu menjadi tanggung jawab pemerintah pusat. Hingga saat ini telah terbit tujuh dari delapan Standar Nasional Pendidikan yang seharusnya dijadikan acuan dalam pengembangan dan penyusunan kurikulum sekolah atau madrasah pada jenjang pendidikan dasar dan menengah.

Dari paparan di atas, dapat dipahami bahwa sekolah atau madrasah memiliki kewenangan yang besar dalam rangka mengembangkan kurikulum untuk memberdayakan berbagai macam potensi yang dimiliki sehingga amanat yang terdapat dalam Undang-undang Nomor 20 Tahun 2003 betul-betul terealisasi secara utuh.

MTsN Model Sumber Bungur Pamekasan, yang merupakan salah satu lembaga pendidikan yang ditetapkan sebagai lembaga pendidikan yang dapat dijadikan sebagai sekolah percontohan, senantiasa melakukan inovasi dan pengembangan kurikulum. Hal ini terlihat pada eksistensi pengembangan kurikulum melalui beberapa kelas program, diantaranya adalah: kelas $\mathrm{Cl}+\mathrm{BI}$, kelas Modul, Kelas Bahasa Arab, 
Kelas Bahasa Inggris, kelas MIPA (Matematika dan IPA), kelas Bahasa Indonesia, kelas IPS (IImu Pengetahuan Sosial), kelas TIK (Teknologi Informasi dan Komunikasi), kelas POK (Pendidikan Olah Raga dan Kesenian), dan kelas Seni Budaya.

Kelas $\mathrm{Cl}+\mathrm{BI}$ merupakan program kelas akselerasi dengan menggunakan kurikulum deferensiasi, kelas Modul menggunakan kurikulum diferensiasi yang menekankan pada aspek pembelajaran dengan menggunakan modul, kelas bahasa Arab menekankan pengembangan kurikulum mata pelajaran PAl dan Bahasa Arab. Kemudian kelas Bahasa Inggris, MIPA, Bahasa Indonesia, IPS, TIK, POK, dan Seni Budaya masing-masing mengorientasikan kurikulum sesuai dengan mata pelajaran yang menjadi fokus utama.

Penelitian ini hendak mengkaji bagaimana konsep dan model pengembangan kurikulum kelas mata pelajaran Bahasa Arab di MTs Negeri Sumber Bungur Pamekasan dan apa saja faktor pendukung dan penghambat pelaksanaan kurikulum tersebut.

\section{Metode Penelitian}

Penelitian ini termasuk dalam kategori penelitian empirik, dengan pendekatan kualitatif, ${ }^{2}$ karena data yang

\footnotetext{
${ }^{2}$ Periksa Basrowi dan Sukidin, Metode Penelitian Kualitatif Perspektif Mikro (Surabaya: Insan Cendekia, 2002), hlm. 2; Lihat juga Imron Arifin, ed., Penelitian Kualitatif dalam IImu-IImu Sosial dan Keagamaan (Malang: Kalimasahada Press, 1996), hlm. 4; S. Nasution, Metode
}

dikumpulkannya bukan dalam bentuk angka, baik interval, ordinal maupun data diskrit sekaligus berusaha menggambarkan realitas sebagaimana adanya (realitas aslinya). Sedangkan jenis penelitian ini adalah eksploratif, yakni studi deskriptif analisis yang lebih mementingkan proses dari pada hasil produk, bersifat induktif, dan lebih mementingkan esensi, ${ }^{3}$ dengan ragam penelitian kasuistis ${ }^{4}$.

Data yang dihimpun adalah datadata yang bersifat kualitatif, yaitu data yang dikategorikan berdasarkan kualitas obyek yang akan diteliti. ${ }^{5} \mathrm{Di}$ antara data yang ingin dihimpun adalah:

1. Konsep kurikulum kelas Mata Pelajaran Bahasa Arab MTs Negeri Sumber Bungur Pamekasan.

2. Aplikasi kurikulum kelas Mata Pelajaran Bahasa Arab MTs Negeri Sumber Bungur Pamekasan.

3. Implementasi kurikulum kelas Mata Pelajaran Bahasa Arab MTs Negeri Sumber Bungur Pamekasan.

4. Pendukung dan penghambat realisasi kurikulum bahasa Arab berbasis Kelas Mata Pelajaran di MTs Negeri Sumber Bungur Pamekasan.

Sumber data dalam penelitian ini, berupa sumber data primer dan data sekunder (penunjang). Data primer

Penelitian Naturalistik-Kualitatif (Bandung: Tarsito, 1988), hlm. 24.

${ }^{3}$ Suharsimi Arikunto, Prosedur Penelitian Suatu Pendekatan Praktik (Jakarta: Bina Aksara,1989), hlm. 9.

${ }^{4}$ Imron Arifin, ed. Penelitian Kualitatif dalam IImu-IImu Sosial dan Keagamaan, hlm. 57.

${ }^{5}$ Sutrisno Hadi, Metodologi Research (Yogyakarta: Andi Offset, 1989), hlm.66. 
diperoleh dari informan atau stakeholder yang terlibat langsung dalam pelaksanaan Pengembangan Kurikulum Bahasa Arab Berbasis Kelas Mata Pelajaran di MTs Negeri Sumber Bungur Pamekasan. Dalam konteks ini, sumber data primer adalah Kepala Madrasah, Pembantu Kepala Madrasah bagian Kurikulum, staf pengajar bahasa Arab dan mata pelajaran Pendidikan Agama Islam di kelas Bahasa Arab.

\section{Sumber data sekunder} (penunjang) adalah sumber data yang diambil dari literatur dan dokumen yang terkait dengan penelitian ini, seperti silabus, RPP, struktur kurikulum, peta lokasi, struktur organisasi, jadwal kegiatan dan lain-lain.

Adapun instrumen pengumpul data dalam penelitian ini adalah observasi non partisipan murni, wawancara mendalam dan dokumentasi. Sedangkan Analisa yang digunakan dalam penelitian ini adalah fungsional and structural prerequisites, yaitu fungsi yang harus sudah ada sebelum unit dibentuk atau didirikan. Demikian pula structural prerequisitis, berarti struktur harus ada sebelum suatu unit dibentuk atau didirikan. ${ }^{6}$ Sedangkan untuk menjaga keabsahan temuan, peneliti melakukan pengecekan keabsahan temuannya dengan: (a) perpanjangan kehadiran, (b) observasi yang diperdalam (observasi lebih lanjut), (c) triangulasi, (d) audit trail mandiri dan (e) pemeriksaan sejawat melalui diskusi.

\section{Hasil Penelitian dan Pembahasan}

Madrasah Tsanawiyah Negeri Sumber Bungur Pamekasan yang dijadikan sebagai obyek penelitian ini tidak serta merta menjadi sebuah institusi atau lembaga besar yang memiliki kualitas mapan dan meraih prestasi maksimal seperti sekarang ini. Akan tetapi ia adalah sebuah lembaga pendidikan yang memiliki sejarah panjang yang dimulai sejak pra kemerdekaan.

Bermula dari sebuah Pondok Pesantren yang dirintis oleh K.H. Muhammad Khalil pada 1921 sampai beliau wafat pada 1950. Lalu sepeninggal Kiai Khalil, kepemimpinan pesantren dilanjutkan oleh saudaranya yang bernama K.H. Abd Majid sampai pada 1957. Kemudian, dua orang putra KH Abd. Majid, yaitu K.H. Madani dan K.H. Ali Makki menggantikan estafeta kepemimpinan pesantren sampai saat ini. $^{7}$

Pondok Pesantren Sumber Bungur memiliki kurang lebih 300 santri mukim yang terdiri dari santri putra dan santri putri. Adapun lembaga pendidikan formal yang mula-mula dikelola oleh Pondok Pesantren ini adalah Taman Pendidikan Al-Qur'an (1989), Madrasah Ibtidaiyah (1936), Madrasah Tsanawiyah (1960) dan Madrasah Aliyah (1987).
${ }^{6}$ A. Khozin Afandi ed., Berpikir Teoritis Merancang Proposal (Surabaya: Pascasarjana IAIN Sunan Ampel Surabaya, 2006), hlm. 29.
${ }^{7} \mathrm{KH}$. Ahmad Madani, Wawancara, Pamekasan, 13 Mei 2013. 
Terkait dengan eksistensi Madrasah Tsanawiyah Negeri yang menjadi obyek penelitian ini, awal mulanya bernama Madrasah Mu'allimin, kemudian pada 1968 berubah menjadi Madrasah Tsanawiyah. Selanjutnya, pada 1972 sampai sekarang, lembaga pendidikan ini berubah status menjadi Madrasah Tsanawiyah Negeri yang secara otomatis pengelolaannya berada di bawah naungan Pemerintah (Kementerian Agama).

Dalam perkembangannya, MTs Negeri Sumber Bungur Pamekasan banyak mengalami kemajuan dan peningkatan, baik dari bertambahnya siswa, lengkapnya fasilitas, maupun tambahan staf pengajar yang profesional di bidangnya. Bahkan terdapat beberapa siswa dari luar Pamekasan bahkan dari luar Madura yang memang sengaja datang (ke MTs Negeri Sumber Bungur Pamekasan) untuk menimba ilmu. Di antara siswa-siswa tersebut ada yang berasal dari Bali, Bandung, Sidoarjo, Surabaya, dan beberapa kota lainnya.

Walaupun letaknya jauh dari Kota Pamekasan, yaitu sekitar $22 \mathrm{Km}$, MTs Negeri Sumber Bungur Pamekasan saat ini diakui memiliki keunggulan kompetetif dan komparatif. Keunggulan kompetetif ditunjukkan oleh prestasi dan kualifikasi siswa yang tidak kalah kemampuan akademik dan kinestetiknya dibandingkan dengan sekolah favorit di daerah perkotaan, seperti SMP 1 dan SMP 2 Pamekasan. Sedangkan keunggulan komparatif ditunjukkan oleh kenyataannya sebagai salah satu lembaga pendidikan atau sekolah percontohan, khususnya di lingkungan kementerian agama wilayah Jawa Timur.

\section{Pengembangan Kurikulum Kelas Mata Pelajaran Bahasa Arab MTs Negeri Sumber Bungur Pamekasan}

Pada awal tahun 2002, orientasi pengembangan kurikulum di MTsN Model Sumber Bungur Pamekasan 3 diarahkan pada pembelajaran dengan mengacu pada kurikulum 1994. Akan tetapi sistem dan penilaian serta model pembelajarannya diorientasikan pada kurikulum 2004, sehingga pada tahun pelajaran 2003-2004, kurikulum 2004 (Kurikulum Berbasis Kompetensi) sudah dilaksanakan secara menyeluruh. Dalam hal ini metode pembelajaran, yang semula menitikberatkan pada metode ceramah dan sebagian praktikum di laboratorium, maka pada tahun pelajaran itu diterapkan model-model pembelajaran seperti CTL (Context Teaching Learning), pembelajaran di dalam dan di luar kelas dengan pendekatan siswa aktif, sehingga guru hanya sebagai fasilitator artinya siswa yang menentukan dan guru yang mengarahkan.

Kemudian pada perkembangan berikutnya, yaitu menerapkan kurikulum baru (2006) dengan tetap menggunakan metode pembelajaran berbasis kompetensi yang sudah disuplementasi dengan kurikulum Tingkat Satuan Pendidikan (KTSP). Kemudian pada tahun 2013, MTs Negeri Sumber Bungur 
Pamekasan "belajar" menerapkan kurikulum 2013. Hal ini sebagaimana dijelaskan oleh Mohammad Holis selaku Kepala Madrasah bahwa:

MTs Sumber Bungur adalah madrasah yang senantiasa melakukan inovasi pada aspek kurikulum. Tidak terkecuali pada upaya melaksanakan kurikulum 2013 yang diprakarsai oleh Mendiknas. Pelaksanaan kurikulum 2013 di MTs Negeri Sumber Bungur Pamekasan tidak secara penuh diterapkan karena Kementerian Agama masih belum memberikan perintah pelaksanaan kurikulum 2013 pada tahun ini melainkan dicanangkan pelaksanaannya pada tahun depan, sehingga saya menggunakan istilah "belajar menggunakan kurikulum 2013”.

Pada dasarnya, pengembangan kurikulum Kelas Mata Pelajaran Bahasa Arab adalah bagian dari pengembangan kurikulum 2006 dengan menekankan pada kebutuhan masyarakat dan eksistensi budaya pesantren. Hal ini disampaikan oleh Edi Subiyanto selaku PKM kurikulum bahwa:

Kurikulum kelas mata pelajaran bahasa Arab adalah pengembangan kurikulum 2006 yang sebenarnya sudah mengarah pada kurikulum 2013. Pengembangan kurikulum kelas bahasa Arab ini menekankan pada kebutuhan masyarakat akan beberapa penguatan materi berbasis arab dan budaya pesantren yang memang cikal bakal MTs Negeri Sumber Bungur Pamekasan. ${ }^{9}$

\section{Berdasarkan penjelasan PKM}

Kurikulum di atas dapat dipahami bahwa kurikulum kelas mata pelajaran Bahasa Arab dikembangkan sebagai upaya

${ }^{8}$ Mohammad Holis, Kepala MTs Negeri Sumber Bungur Pamekasan, Wawancara, Pamekasan, 13 Mei 2013.

${ }^{9}$ Edi Subiyanto, PKM Kurikulum MTs Negeri Sumber Bungur Pamekasan, Wawancara, Pamekasan, 13 Mei 2013. penyesuaian kurikulum secara berkala dengan perkembangan atau perubahan yang terjadi dalam masyarakat serta tuntutan budaya pesantren yang merupakan cikal bakal MTs Negeri Sumber Bungur Pamekasan.

Adapun bentuk pengembangan Kurikulum Kelas Mata Pelajaran Bahasa Arab MTs Negeri Sumber Bungur Pamekasan meliputi: 1). Perumusan latar belakang, 2). Landasan hukum, 3). Perumusan tujuan, 4). Penentuan alokasi waktu, 5). Perumusan Standar Kompetensi (SK) dan Kompetensi Dasar (KD) mata pelajaran Bahasa Arab. ${ }^{10}$

\section{Latar Belakang}

Bahasa Arab adalah bahasa alQur'an, bahasa ibadah umat Islam secara keseluruhan, dan bahasa internasional ketiga setelah bahasa Inggris dan Perancis. Dikatakan demikian karena sudah mafhum, bahwa al-Qur'an sebagai kitab suci ditulis dalam bahasa Arab, dengan demikian ia tidak dapat dipisahkan dari medium ekspresi linguistiknya. Secara makro, bahasa Arab adalah bahasa mayoritas umat Islam di dunia, dimana ia digunakan sebagai alat komunikasi dan informasi dalam keseharian, baik secara langsung maupun melalui media cetak dan elektronik.

Di Indonesia, idealitas entitas bahasa Arab di atas ternyata tidak

\footnotetext{
${ }^{10}$ Hasil wawancara dengan Moch Cholid, Ketua Program Kelas Mata Pelajaran Bahasa Arab MTs Negeri Sumber Bungur Pamekasan, pada tanggal 15 Mei 2013.
} 
diimbangi dengan realitas obyektif dalam pembelajaran. Sebuah keironisan ketika melihat kompleksitas permasalahan dalam proses pembelajaran bahasa Arab dari tingkat madrasah ibtidaiyah hingga perguruan tinggi. Kemampuan berbahasa Arab yang telah diyakini sebagai syarat bagi setiap individu yang melakukan kajian keilmuan umum maupun keislaman sampai saat ini tidaklah menggembirakan. Pembelajaran bahasa Arab jauh tertinggal, baik dari sisi substansi kajian, kurikulum, maupun metode pembelajaran.

Pengalaman di lapangan menunjukkan bahwa: (1) nilai kemampuan bahasa Arab untuk lulusan MTs dan MA yang masih di bawah standar, (2) hasil ujian masuk PTAI menunjukkan hasil rata-rata peserta tes yang sangat tidak memuaskan, dan kalaupun ada peserta yang memiliki talenta kemampuan berbahasa Arab yang baik, mereka adalah yang latar belakang pendidikannya dari pondok pesantren atau lulusan Madrasah Aliyah Program Khusus (MAN-PK), (3) pelajaran bahasa Arab masih dipandang sebagai momok yang menakutkan bagi sebagian siswa, pelajaran yang begitu linier, menjemukan, memberatkan (karena terlalu dibebani dengan sederet hafalan teks), disikapi dengan defensif, dan yang lebih parah lagi menganggap bahasa Arab sebagai "anak tiri", pelajaran yang tidak penting. Sehingga tak jarang terdapat antipati untuk mengikuti pembelajaran dimaksud.

Berdasarkan paparan di atas, kompleksitas problem pembelajaran bahasa Arab di Indonesia. Harus segera disikapi dan dicarikan solusi secara inten mengingat begitu besarnya signifikansi penguasaan bahasa Arab, terutama bagi seorang muslim.

MTs Negeri Sumber Bungur Pamekasan yang senantiasa melakukan inovasi pembelajaran dan pengembangan kurikulum ingin menjawab problem tersebut dengan melakukan pengembangan kurikulum pembelajaran Bahasa Arab sebagai upaya penguatan bagi siswa dan siswa kelas Mata Pelajaran Bahasa Arab agar memiliki kemampuan berkomunikasi Bahasa Arab dalam pengertian yang utuh, yaitu kemampuan memahami dan atau menghasilkan teks lisan dan atau tulis yang direalisasikan dalam empat keterampilan berbahasa, yaitu mendengarkan (istima'), berbicara (kalam), membaca (qira'ah) dan menulis (kitabah).

2. Landasan Hukum
a. Undang-undang Dasar 1945
b. Undang-undang Nomor 20 Tahun 2003 tentang Sistem Pendidikan Nasional
c. Peraturan Pemerintah Republik Indonesia Nomor 19 Tahun 2005 
tentang Standar Nasional Pendidikan

d. Permendiknas RI Nomor 22 Tahun 2006 tentang Standar Isi untuk satuan Pendidikan Dasar dan Menengah

e. Permendiknas RI Nomor 23 Tahun 2006 tentang Standar Kompetensi Lulusan untuk satuan Pendidikan Dasar dan Menengah

f. Permendiknas RI Nomor 24 Tahun 2006 tentang pelaksanaan Permendiknas Nomor 22 dan 23 Tahun 2006

g. Visi dan Misi Kementerian Agama Republik Indonesia

h. Visi, misi dan tujuan MTs Negeri Sumber Bungur Pamekasan

i. Kurikulum Tingkat Satuan Pendidikan MTs Negeri Sumber Bungur Pamekasan

j. Keputusan rapat dinas dewan guru MTs Negeri Sumber Bungur Pamekasan tanggal 10 Pebruari 2009 tentang pembentukan kelas Mata Pelajaran

3. Perumusan Tujuan

a. Tujuan Umum:

Memberikan penguatan materi Bahasa Arab dalam dalam empat aspek keterampilan berbahasa, yaitu mendengarkan (istima'), berbicara (kalam), membaca (qira'ah) dan menulis (kitabah).

b. Tujuan khusus:

- Mencapai tingkat kemampuan berbahasa yang mencakup performative, functional, informational, dan epistemic. Pada tingkat performative, siswa diharapkan mampu membaca (fahm maqru'), menulis (kafa'ah al-kitabah), mendengarkan (fahm almasmu'), dan berbicara dengan simbol-simbol (al-kalam bi ramuz al-shauti) yang digunakan. Pada tingkat functional, siswa diharapkan mampu menggunakan bahasa Arab untuk memenuhi kebutuhan hidup sehari-hari seperti membaca surat kabar (qiro'ah al-jaridah), manual atau petunjuk. Pada tingkat informational, siswa diharapkan mampu mengakses pengetahuan dengan kemampuan berbahasa, sedangkan pada tingkat epistemic siswa diharapkan mampu mengungkapkan pengetahuan ke dalam bahasa sasaran.

- Mencetak siswa yang terampil berbahasa yang mencakup masalah ketrampilan berbicara (maharah al-kalam), menyimak (maharah al-istima'), membaca (maharah al-qira'ah) dan menulis (maharah al-kitabah).

4. Penentuan Alokasi Waktu

Alokasi waktu mata pelajaran Bahasa Arab yang disediakan untuk kelas Mata Pelajaran Bahasa Arab adalah 8 Jam Tatap Muka (8X40 menit). Dengan rincian 4 jam 
pelajaran untuk mata pelajaran bahasa arab, 2 jam pelajaran untuk pelajaran nahwu dan 2 jam pelajaran untuk mata pelajaran sorrof.

\section{Perumusan SK dan KD}

\section{Untuk Standar Kompetensi}

dan Kompetensi Dasar mata pelajaran Bahasa Arab disesuaikan dengan Permenag Nomor 2 Tahun 2008, dengan tambahan Standar Kompetensi dan Kompetensi Dasar untuk mata pelajaran Nahwu dan Shorrof sebagai berikut:

\begin{tabular}{|c|c|c|}
\hline NO & STANDAR KOMPETENSI & KOMPETENSI DASAR \\
\hline 1 & $\begin{array}{l}\text { Memahami kalam dan bentuk } \\
\text { susunannya }\end{array}$ & $\begin{array}{l}\text { 1.1 Memahami pengertian kalimah } \\
\text { 1.2 Memahami tanda-tanda isim } \\
\text { 1.3 Memahami tanda-tanda fi'il } \\
\text { 1.4 Memahami pembagian fi'il } \\
\text { 1.5 Memahami tanda-tanda huruf }\end{array}$ \\
\hline 2 & Memahami I'rab dan Bina' & $\begin{array}{l}\text { 2.1 } \text { Memahami pengertian l'rab } \\
\text { 2.2 } \text { Memahami pembagian I'rab } \\
\text { 2.3 Mengetahui sesuatu yang boleh memasuki Isim dan Fi'il } \\
\text { 2.4 Memahami definisi Bina' (mabni) } \\
\text { 2.5 Memahami isim mu'rab dan isim mabni } \\
\text { 2.6 Memahami isim-isim yang dimabnikan } \\
\text { 2.7 } \text { Memahami fi'il mabni dan fi'il mu'rab }\end{array}$ \\
\hline 3 & Memahami tanda-tanda I'rab & $\begin{array}{l}\text { 1.1 Memahami tanda i'rab rofa' } \\
\text { 1.2 Memahami tanda i'rab jar } \\
\text { 1.3 Memahami tanda i'rab jazm } \\
\text { 1.4 Memahami lafadz yang di i'rab dengan harakat dan huruf } \\
\text { 1.5 Memahami ketentuan i'rab isim tatsniyah, jama' } \\
\text { mudzakkar salim, asma'us sittah, lafadz hanu, dan } \\
\text { amtsilatul khamsah } \\
\text { 1.6 Memahami i'rab fi'il mu'tal }\end{array}$ \\
\hline 4 & $\begin{array}{l}\text { Memahami Isim Nakirah dan } \\
\text { Isim Ma'rifah }\end{array}$ & $\begin{array}{l}\text { 4.1 Memahami macam-macam isim dhomir } \\
\text { 4.2 Memahami isim dhomir muttasil dan munfasil } \\
\text { 4.3 Mamahami isim alam, isyarah dan maushul }\end{array}$ \\
\hline
\end{tabular}

Kelas 8
\begin{tabular}{|c|l|ll|}
\hline NO & STANDAR KOMPETENSI & \multicolumn{1}{c|}{ KOMPETENSI DASAR } \\
\hline 1 & Memahami isim yang & 1.1 & Memahami fa'il \\
& dirofa'kan & 1.2 & Memahami maful yang tidak disebut failnya \\
& & 1.3 & Memahami mubtada' dan khabar \\
& & 1.4 & Memahami amil-amil yang masuk pada mubtada' dan \\
& & 1.5 & kemabar \\
& & 1.6 & Memahami kana, inna, dzanna dan saudara-saudaranya \\
\hline 2 & Memahami isim yang & 2.1 & Memahami maf'ul bih dan maf'ul muqaddam \\
& dinashabkan & 2.2 & Memahami maf'ul mutlaq dan pembagiannya \\
& & 2.3 & Memahami Maf'ul fih \\
& & 2.4 & Memahami maf'ul min ajlih \\
& & 2.5 & Memahami maf'ul ma'a dan sifat yang menyerupai isim fail \\
\hline
\end{tabular}

Kelas 9
\begin{tabular}{|c|lc|cl|}
\hline NO & STANDAR KOMPETENSI & & \multicolumn{1}{c|}{ KOMPETENSI DASAR } \\
\hline 1 & Memahami isim yang & 1.1 & Memahami hal \\
& dinashabkan & 1.2 & Memahami tamyiz \\
& & 1.3 & Memahami mustatsna dan ketentuannya \\
& & 1.4 & Ketentuan i'rab lafadz khala, 'ada dan hasya \\
\hline 2 & Memahami isim-isim yang & 2.1 & Memahami pengertian idhafah \\
& dijarkan & 2.2 & Memahami pembagian idhafah \\
\hline 3 & l'rab fi'il mudhara'ah & 3.1 & Memahami awamilun nasbi dan pembagiaannya \\
& & 3.2 & Memahami 'awamilul jazm \\
\hline
\end{tabular}




\begin{tabular}{|c|l|ll|}
\hline 4 & Memahami Naat & 4.1 Memahami pengertian naat \\
& & 4.2 Memahami konsep dasar naat \\
\hline 5 & Memahami 'athaf & 5.1 Memahami ketentuan 'athaf bayan dan athaf nasaq \\
& & 5.2 Memahami fungsi huruf 'athaf \\
\hline 6 & Memahami taukid & 6.2 Memahami pengertian taukid \\
& & 6.3 Memahami bentuk-bentuk taukid \\
\hline 7 & Memahami badal & 7.2 Memahami pengertian badal \\
& & 7.3 Memahami macam-macam badal \\
\hline
\end{tabular}

Sharraf (Kelas 7)

\begin{tabular}{|c|c|c|}
\hline NO & STANDAR KOMPETENSI & KOMPETENSI DASAR \\
\hline 1 & $\begin{array}{l}\text { Memahami konsep dasar ilmu } \\
\text { sharraf }\end{array}$ & $\begin{array}{l}\text { 1.1 Memahami pengertian ilmu sharraf } \\
\text { 1.2 Memahami pengertian bina' dan macam-macamnya } \\
\text { 1.3 Memahami pengertian shighat dan macam-macamnya } \\
\text { 1.4 Memahami wazan-wazan sharfi } \\
\text { 1.5 Memahami fi'il mujarrad dan mazid } \\
\text { 1.6 Memahami fi'il ma'mul dan majhul }\end{array}$ \\
\hline 2 & Memahami tashrif istilahi & $\begin{array}{l}\text { 2.1 Memahami cara mentashrif bina' shahih secara istilahi } \\
\text { 2.2 Memahami cara mentashrif bina' mahmuz secara istilahi } \\
\text { 2.3 Memahami cara mentashrif bina' mudha'af secara } \\
\text { istilahi } \\
\text { 2.4 Memahami cara mentashrif bina' mitsal secara istilahi } \\
\text { 2.5 Memahami cara mentashrif bina' ajwaf secara istilahi } \\
\text { 2.6 Memahami cara mentashrif bina' naqish secara istilahi }\end{array}$ \\
\hline
\end{tabular}

Kelas 8

\begin{tabular}{|c|l|ll|}
\hline NO & STANDAR KOMPETENSI & \multicolumn{1}{c|}{ KOMPETENSI DASAR } \\
\hline 1 & Memahami tashrif istilahi & 1.1 & Memahami cara mentashrif bina' lafif mafruq secara istilahi \\
& & 1.2 & Memahami cara mentashrif bina' lafif maqun secara istilahi \\
& & 1.3 & Memahami cara mentasfrif fi'il ruba'i mujarrad dan mazid \\
\hline 2 & Memahami tashrif lughawi & 2.1 & Memahami cara mentashrif bina' shahih secara lughawi \\
& & 2.2 & Memahami cara mentashrif bina' mudha'af secara istilahi \\
& & 2.3 & Memahami cara mentashrif bina' mahmuz secara istilahi \\
& & 2.4 & Memahami cara mentashrif bina' mitsal secara istilahi \\
& & 2.5 & Memahami cara mentashrif bina' ajwaf secara istilahi \\
& & 2.6 & Memahami cara mentashrif bina' naqish secara istilahi \\
& & 2.7 & Memahami cara mentashrif bina' lafif secara istilahi \\
& & 2.8 & Memahami cara mentashrif isim fa'il marfu' secara istilahi \\
\hline
\end{tabular}

\begin{tabular}{|c|c|c|}
\hline NO & STANDAR KOMPETENSI & KOMPETENSI DASAR \\
\hline 1 & Memahami tasfrif lughawi & $\begin{array}{l}\text { 1.1 Memahami cara mentashrif isim maf'ul marfu' secara istilahi } \\
\text { 1.2 Memahami cara mentashrif fi'il mudhari' mabni fa'il yang } \\
\text { bersambung dengan nun taukid tsaqilah secara istilahi } \\
\text { 1.3 Memahami cara mentashrif fi'il mudhari' mabni fa'il yang } \\
\text { bersambung dengan nun taukid khafifah secara istilahi } \\
\text { 1.4 Memahami cara mentashrif fi'il amar lil ghaib dan hadir mabni } \\
\text { fa'il yang bersambung dengan nun taukid tsaqilah secara } \\
\text { istilahi }\end{array}$ \\
\hline 2 & $\begin{array}{l}\text { Memahami faidah-faidah } \\
\text { peribahan wazan }\end{array}$ & $\begin{array}{l}\text { 2.1 Memahami faidah-faidah wazan fi'il tsulatsi mazid ruba'i } \\
\text { 2.2 Memahami faidah-faidah wazan fi'il tsulatsi mazid khumasi } \\
\text { 2.3 Memahami faidah-faidah wazan fi'il tsulatsi mazid sudasi } \\
\text { 2.4 Memahami faidah-faidah wazan fi'il ruba'i mazid khumasi } \\
\text { 2.5 Memahami faidah-faidah wazan fi'il ruba'i mazid sudasi } \\
\text { 2.6 Memahami faidah-faidah wazan fi'il ruba'i mulhaq }\end{array}$ \\
\hline
\end{tabular}


Keseluruhan pendalaman materi tersebut diorientasikan pada penguatan maharatul istima', kalam, qiro'ah dan kitabah dengan tanpa mengesampingkan konten kitabkitab yang dikaji. Misalnya fiqh yang berorientasi pada tata cara ibadah dan tafsir yang berorientasi pada pemahaman terhadap al-Qur'an secara utuh.

Berdasarkan beberapa keterangan di atas dapat disimpulkan bahwa kelas mata pelajaran bahasa Arab adalah kelas yang alokasi waktu mata pelajaran bahasa Arab dan PAl terdapat penambahan jam pelajaran, yaitu bahasa Arab menjadi 8 jam dan mata pelajaran PAI menjadi 4 jam. Hal ini sebagaimana diungkapkan oleh Moch Cholid bahwa:

Kelas mata pelajaran bahasa Arab adalah kelas dengan penambahan jam pada mata pelajaran bahasa Arab dan PAI. Hal ini dilakukan agar supaya siswa betul menguasai bahasa Arab dan pengetahuan agama lainnya jauh di atas teman-temannya yang lain. Hal ini dapat dibuktikan dengan tercapainya prestasi siswa yang bisa merubah fi'il-fi'il baik yang shohih maupun yang mu'tal pada beberapa bentuk fi'il tsulatsi mazid. ${ }^{11}$

Terkait dengan guru dan murid yang ada di kelas mata pelajaran Bahasa Arab, Edi Subiyanto menjelaskan bahwa:

Ada beberapa persyaratan bagi siswa yang ingin belajar di kelas mata pelajaran Bahasa Arab. Diantaranya ada lulus dalam tes seleksi tulis, wawancara pengetahuan bahasa Arab dan agama, memiliki nilai 75 untuk mata pelaharan

11 Ibid.
PAl dan Bahasa Arab bagi siswa Madrasah Ibtidaiyah dan nilai 75 dengan menyertakan bukti pernah mengenyam pendidikan madrasah diniyah bagi siswa sekolah dasar.

Sedangkan guru yang mengajar adalah guru yang benar-benar profesional di bidangnya masing-masing serta pernah mengenyam pendidikan pesantren. ${ }^{12}$

Berdasarkan keterangan di atas, dapat disimpulkan bahwa baik guru maupun murid yang ada di kelas mata pelajaran bahasa Arab adalah orang pilihan yang kompetensinya tidak diragukan lagi. $\mathrm{Hal}$ ini sangat berpengaruh terhadap ketercapaian pembelajaran sesuai dengan Standar Kompetensi dan Kompetensi Dasar yang sudah ditentukan.

Faktor Pendukung dan Penghambat Pelaksanaan Kurikulum Kelas Mata Pelajaran Bahasa Arab MTs Negeri Sumber Bungur Pamekasan

Dalam rangka pengembangan kurikulum kelas mata pelajaran bahasa arab di MTs Negeri Sumber Bungur Pamekasan, terdapat faktor-faktor yang mempengaruhinya, baik itu berupa faktor pendukung maupun faktor penghambat.

1. Faktor Pendukung

Di antara faktor pendukung pelaksanaan kurikulum kelas mata pelajaran bahasa Arab MTs Negeri Sumber Bungur Pamekasan adalah:

${ }^{12}$ Edi Subiyanto, PKM Kurikulum MTs Negeri Sumber Bungur Pamekasan, Wawancara, 15 Mei 2013. 
a. Motivasi Kanwil Kemenag

Menurut Mohammad Holis yang sekarang menjabat sebagai Kepala Madrasah, ide awal yang kemudian menjadi inspirasi pengembangan kurikulum berbasis kelas mata pelajaran adalah pemberian sebuah buku yang berjudul "The Shaping School Culture" oleh salah seorang pejabat di Mapenda Kanwil Kemenag Jawa Timur.

Beberapa tahun yang lalu, saya diberi sebuah buku oleh Pak Suprat yang pada waktu itu akan berangkat ke Australia untuk melanjutkan kuliah S3. Judul buku itu adalah "The Shaping School Culture". Beliau mengatakan: Coba baca buku ini kemudian kembangkan di madrasah ini. Setelah saya baca dengan dibantu beberapa teman, akhirnya saya bertekad untuk mengembangkan "school culture" dengan menggunakan istilah "kelas mata pelajaran". ${ }^{13}$

Tidak hanya pada aspek pemberian buku, Mapenda Kanwil Kemenag Jawa Timur senantiasa memantau kurikulum yang dibuat Pamekasan dan senantiasa meminta salinannya dalam setiap tahun untuk mengetahui perkembangan yang sudah dilakukan. Hal ini secara tidak langsung memberikan dukungan moral kepada Madrasah agar senantiasa mengembangkan kurikulum. oleh MTs Sumber Bungur

Selain itu, pengembangan kurikulum yang sudah dibuat MTs Negeri Sumber Bungur Pamekasan juga sudah mendapatkan legalisasi dari Kantor Wilayah Kementerian Agama Jawa Timur.

b. Komitmen Kepala Madrasah

Kepala MTs Negeri Sumber Bungur Pamekasan senantiasa berupaya mengembangkan kurikulum berdasarkan ketercapaian tujuan pendidikan yang ideal. Hal ini terbukti dengan adanya penekanan pengembangan kurikulum yang berorientasi ke "masa depan". Dia mengatakan:

MTs Sumber Bungur tidak akan pernah berhenti untuk mengembangkan kurikulum dari masa ke masa. Hal ini sudah menjadi tekad saya sebagai kepala madrasah untuk menjadi pengembangan kurikulum sebagai pedoman penyelenggaraan pendidikan. Di samping itu, saya juga memberikan fasilitas dan media pembelajaran yang cukup memadai untuk menunjang kegiatan pembelajaran. $^{14}$

Berdasarkan keterangan di atas, dapat ditarik kesimpulan bahwa Kepala MTs Negeri Sumber Bungur Pamekasan memiliki komitmen yang kuat untuk mengembangkan kurikulum terutama kurikulum kelas Mata Pelajaran. Komitmen ini memiliki

${ }^{14}$ Mohammad Holis, Kepala MTs Negeri

${ }^{13}$ Mohammad Holis, Kepala MTs Negeri Sumber Bungur Pamekasan, Wawancara, 13 Mei 2013. 


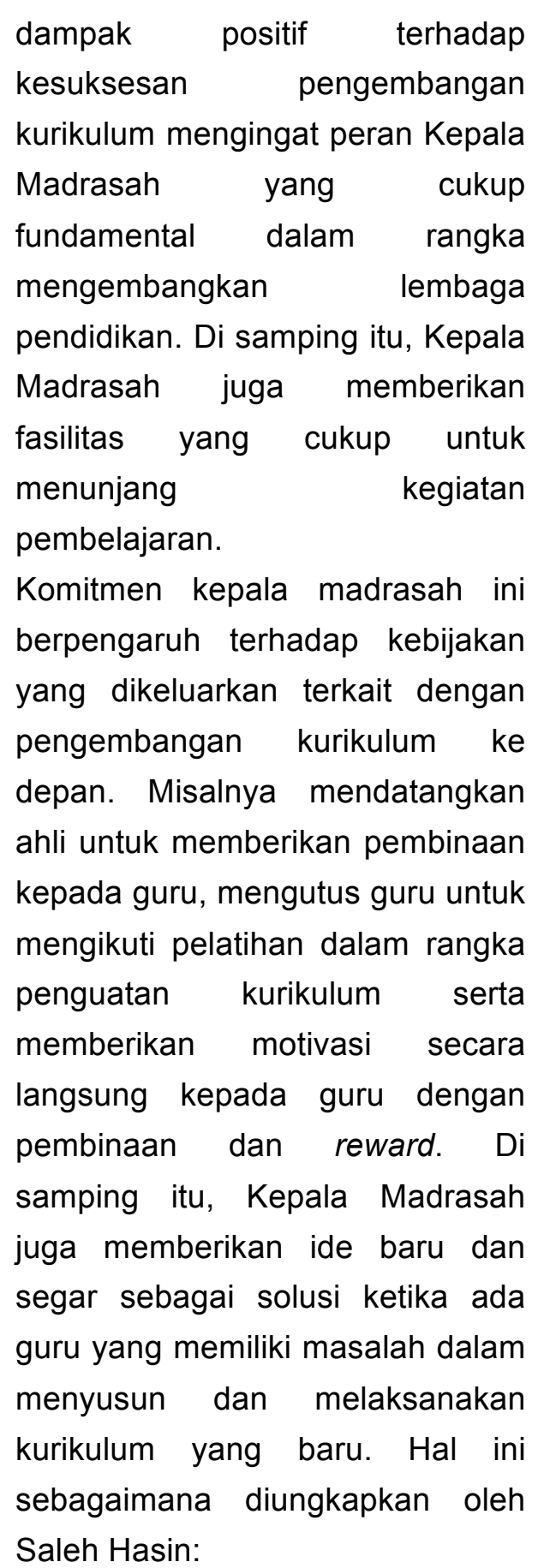

Terus terang saja, kepala madrasah kami selalu memberikan dukungan terhadap pengembangan kurikulum yang berorientasi pada masa depan. Hal ini terlihat pada pemberian ide-ide baru terkait kurikulum, selalu memberikan inspirasi kepada guru, memberikan fasilitas untuk mengembangkan kurikulum seperti mengirim delegasi untuk mengikuti pelatihan, mendatangkan nara sumber, memberikan pembinaan dan reward kepada guru yang berprestasi serta tidak pernah berhenti memberikan solusi ketika para guru memiliki kendala. ${ }^{15}$

Berdasarkan keterangan di atas, Kepala MTs Sumber Bungur Pamekasan benar-benar memiliki andil yang cukup besar dalam meningkatkan kualitas pembelajaran terutama melalui inovasi kurikulum.

\section{c. Kompetensi Profesional Guru}

Eksistensi guru sebagai inovator, menuntut guru untuk menemukan strategi, metode atau konsepkonsep baru dalam dunia pendidikan dan pembelajaran. ${ }^{16}$ Hal ini juga berlaku pada wilayah pengembangan kurikulum dan kemampuan untuk mengimplementasikannya.

Menurut Edi Subiyanto, guru pada kelas mata pelajaran sudah secara maksimal disesuaikan dengan kompetensi yang dimiliki:

Saya dan kepala Madrasah melakukan supervisi untuk memilih guru yang tepat pada masing-masing kelas mata pelajaran. Untuk kelas mata pelajaran bahasa Arab, kami memilih guru PAI dan Bahasa Arab yang memiliki kemampuan lebih dan disiplin yang tinggi serta tercatat sebagai alumni pesantren (santri). ${ }^{17}$

${ }^{15}$ Moh Saleh Hasin, PKM P2M MTs Negeri Sumber Bungur Pamekasan, Wawancara, 15 Mei 2013.

${ }^{16}$ Moh. Uzer Usman, Menjadi Guru, 11. Lihat juga: Ahmad Sabri, Strategi Belajar Mengajar dan Micro Teaching (Jakarta: Quantum Teaching, 2005), hlm. 74.

${ }^{17}$ Edi Subiyanto, PKM Kurikulum MTs Negeri Sumber Bungur Pamekasan, Wawancara, 13 Mei 2013. 
Berdasarkan keterangan di atas, dapat dikatakan bahwa guru pada kelas Mata Pelajaran Bahasa Arab adalah guru pilihan yang memiliki kompetensi yang baik dibidangnya, memiliki disiplin tinggi dan alumni salah satu pesantren. Hal ini dijadikan sebagai syarat agar supaya dalam proses pembelajaran dan implementasi kurikulumnya tidak mendapatkan kendala yang berarti.

d. Eksistensi Pesantren Sumber Bungur

Lingkungan yang kondusif merupakan salah satu faktor pendukung suksesnya pelaksanaan pengembangan kurikulum. Pada kelas Mata Pelajaran Bahasa Arab, Pondok Pesantren adalah lingkungan yang menjadi mitra utama dalam mengembangkan kurikulum. Hal ini dikarenakan muatan kurikulum yang sudah disampaikan sebelumnya, berorientasi pada upaya memaksimalkan materi agama dan Bahasa Arab. Keberadaan Madrasah yang ada di lingkungan Pesantren Sumber Bungur memiliki nilai lebih dalam mengembangkan kurikulum Mata Pelajaran Bahasa Arab. Sebagaimana disampaikan oleh Moch Cholid bahwa:

Kelas mata pelajaran Bahasa Arab yang materinya diorientasikan pada mata pelajaran agama dan Bahasa Arab mendapatkan pengaruh secara langsung dari Pesantren karena ketika siswa secara maksimal dan prosedural mendapatkan materi agama dan Bahasa Arab di Madrasah, mereka akan melanjutkan, mendalami dan menguatkan pemahamannya di Pesantren. $^{18}$

Berdasarkan keterangan di atas, Pesantren adalah pusat pengembangan pendidikan siswa yang telah diperoleh sehingga ketika siswa yang mendapatkan materi, maka mereka akan melanjutkan, mendalami dan menguatkan materi yang telah diperoleh sebelumnya. Demikian pula sebaliknya, materi yang didapat dari Pesantren akan dikuatkan dan menjadi bahan dalam berdiskusi di Madrasah. Jadi akan terjadi umpan balik dari siswa baik pembelajaran di Madrasah maupun di Pesantren.

e. Input Siswa

Input siswa adalah salah satu faktor pendukung terlaksananya pengembangan kurikulum mata pelajaran Bahasa Arab di MTs Negeri Sumber Bungur Pamekasan. Sebagaimana disampaikan oleh Edi Subiyanto:

Siswa yang masuk pada kelas mata pelajaran adalah siswa yang memiliki modal untuk mengembangkan potensi sesuai dengan bidang yang dimilikinya. Tidak terkecuali kelas Bahasa Arab. Artinya siswa yang siap mendalami mata

${ }^{18}$ Moch Cholid, Ketua Program Kelas Mata Pelajaran Bahasa Arab MTs Negeri Sumber Bungur Pamekasan, Wawancara, 15 Mei 2013. 
pelajaran PAI dan Bahasa Arab akan memiliki kemampuan yang berbeda dengan siswa yang tidak memiliki modal pengetahuan sama sekali. ${ }^{19}$

Pernyataan yang sama juga diberikan oleh Abdul Haq selaku wali kelas mata pelajaran Bahasa Arab, bahwa:

Siswa yang masuk di kelas mata pelajaran Bahasa Arab adalah siswa yang sudah memiliki kemampuan sebagai modal awal untuk mengembangkan potensi yang dimilikinya. Oleh karenanya, diadakan tes dalam rekrutmen siswa untuk mengetahui pengetahuan yang dimiliki oleh siswa terutama pada materi PAI dan Bahasa Arab

Berdasarkan keterangan tersebut, dapat disimpulkan bahwa siswa yang akan masuk pada kelas mata pelajaran Bahasa Arab harus lulus tes seleksi dan syarat khusus seperti miliki nilai minimal 75 pada mata pelajaran PAI dan Bahasa Arab pada tingkat dasar.

\section{Faktor Penghambat}

Kendatipun terdapat beberapa faktor yang mendukung pelaksanaan kurikulum kelas mata pelajaran Bahasa Arab, terdapat kendala yang dihadapi dalam mengimplementasikan pengembangan kurikulum kelas mata pelajaran Bahasa Arab MTs Negeri Sumber Bungur Pamekasan, diantarangan adalah:

a. Alokasi dana
Kelas mata pelajaran Bahasa Arab adalah salah satu kelas unggulan di MTs Negeri Sumber Bungur Pamekasan. Sebenarnya kelas ini memiliki kebutuhan yang cukup banyak dari sisi infrastruktur maupun pengembangan administrasi kurikulum. Hal ini sebagaimana diungkapkan oleh Moch Cholid:

Pendanaan adalah salah satu masalah yang dihadapi MTs Sumber Bungur dalam upaya melakukan pengembangan bidang kurikulum. Misalnya pada kelas mata pelajaran Bahasa Arab, pemberian insentif pada guru pengajar yang dituntut lebih profesional dari pada guru pada kelas lain masih belum ada, demikian halnya dengan pembuatan yang berkaitan dengan administrasi kurikulum masih belum ada anggaran khusus sehingga guru tidak termotivasi secara maksimal. Disamping itu, pengadaan kelas yang representatif untuk mengatasi kejenuhan siswa masih jauh dari ideal. ${ }^{20}$

Berdasarkan keterangan di atas, dana menjadi salah satu faktor penghambat pengembangan kurikulum kelas mata pelajaran bahasa Arab karena tidak adanya alokasi khusus untuk membuat kelas yang representatif dan pemberian insentif yang ideal untuk guru.

b. Penyusunan Kurikulum Hambatan utama pengembangan kurikulum kelas mata pelajaran di MTs Negeri
${ }^{19}$ Edi Subiyanto, PKM Kurikulum MTs Negeri Sumber Bungur Pamekasan, Wawancara, 13 Mei 2013.
${ }^{20}$ Moch Cholid , Ketua Program Kelas Mata Pelajaran Bahasa Arab MTs Negeri Sumber Bungur Pamekasan, Wawancara, 15 Mei 2013. 


\author{
Sumber Bungur Pamekasan \\ adalah penyusunan \\ kurikulumnya. Hal ini \\ dikarenakan masih belum ada \\ pedoman yang bisa dijadikan \\ sebagai acuan dasar dalam \\ menyusun kurikulum. \\ Sebagaimana dikatakan oleh \\ Mohammad Holis bahwa:
}

Penyusunan kurikulum kelas mata pelajaran Bahasa Arab hanya mengacu pada konsep dasar yang ada dalam buku "The Shaping Shool Culture" karya Peterson. Hal ini karena memang belum ada panduan ataupun pedoman khusus penyelenggaraan kelas mata pelajaran Bahasa Arab. Oleh karenanya, saya sebagai Kepala Madrasah dengan dibantu oleh PKM Kurikulum, Ketua Program dan guru pengajar berupaya merumuskan kurikulum yang ideal dengan segala keterbatasan referensi sehingga dalam setiap tahunnya pasti mengalami perubahan sebagai upaya pembenahan menuju arah yang lebih baik. $^{21}$

Berdasarkan keterangan di atas, acuan penyelenggaraan kelas mata pelajaran bahasa Arab memang belum ada. Sehingga pihak madrasah, baik Kepala dan guru, merasa kesulitan untuk menemukan format kurikulum yang sesuai dengan peraturan. Oleh karenanya, secara independen mereka merumuskan sendiri kurikulum yang direvisi dalam setiap tahunnya agar supaya lebih mendekati idealitas.

\footnotetext{
${ }^{21}$ Mohammad Holis, Kepala MTs Negeri
} Sumber Bungur Pamekasan, Wawancara, 13 Mei 2013. c. Ketidakmerataan kemampuan guru pengajar

Peran guru yang cukup banyak $^{22}$ seperti edukator, manager, administrator, supervisor, leader, inovator, motivator, dinamisator, evaluator dan fasilitator berdampak pada sulitnya mencari guru yang siap menjadi bagian dari kelas mata pelajaran Bahasa Arab. Hal ini diungkapkan oleh Edi Subiyanto:

Mencari guru yang pas di kelas mata pelajaran bahasa arab memang cukup sulit mengingat tidak semua guru siap menagajar secara maksimal di kelas ini. Misalnya tidak semua guru bahasa arab dapat menguasai kitab nahwu dan shorrof, tidak semua guru qur'an hadits yang menguasai tafsir dan tidak semua guru figh mampu menguasai kitab fiqh klasik. $^{23}$

Berdasarkan keterangan PKM Kurikulum di atas, guru PAI dan Bahasa Arab di MTs Negeri Sumber Bungur Pamekasan tidak secara keseluruhan siap mengajar di kelas mata pelajaran bahasa Arab mengingat kompetensi yang dimiliki tidak cukup syarat untuk mengajar di kelas ini. Misalnya guru bahasa Arab harus menguasai kitan nahwu dan

${ }^{22}$ Syaiful Bahri Djamarah, Guru dan Anak Didik dalam Interaksi Edukatif (Jakarta: Rineka Cipta, 2003), hlm. 38-39.

${ }^{23}$ Edi Subiyanto, PKM Kurikulum MTs Negeri Sumber Bungur Pamekasan, Wawancara, 15 Mei 2013. 
shorrof, guru Qur'an Hadits harus menguasai tafsir dan guru fiqh harus menguasai kitab fiqh klasik.

d. Psikologi siswa

Kelas Mata Pelajaran Bahasa Arab berupaya untuk mencetak siswa yang terampil berbahasa yang mencakup masalah ketrampilan berbicara (maharah al-kalam), menyimak (maharah al-istima'), membaca (maharah al-qira'ah) dan menulis (maharah al-kitabah). Kemampuan tersebut dapat direalisasikan dengan penambahan jam pelajaran, yaitu: Alokasi waktu mata pelajaran Bahasa Arab yang disediakan untuk kelas Mata Pelajaran Bahasa Arab adalah 8 Jam Tatap Muka (8X40 menit). Dengan rincian 4 jam pelajaran untuk mata pelajaran bahasa arab, 2 jam pelajaran untuk pelajaran nahwu dan 2 jam pelajaran untuk mata pelajaran sorrof. Kemudian untuk mata pelajaran PAl yang di orientasikan pada penguasaan bahasa, masingmasing ditambah 2 jam pelajaran sehingga menjadi 4 jam pelajaran. Hal ini sebagaimana dikemukakan oleh Moch Cholid bahwa:

Sebagai upaya optimalisasi pembelajaran agar siswa dan siswi kelas mata pelajaran Bahasa Arab mampu mencapai tujuan pembelajaran, maka ada penambahan alokasi waktu, yaitu: untuk Bahasa arab dari 3 jam pelajaran menjadi 8 jam pelajaran, untuk mata pelajaran PAl masing-masing ditambah 2 jam sehingga menjadi 4 jam. Jadi total jam pelajaran PAI dan Bahasa Arab yang semestinya adalah 11 jam pelajaran untuk kelas lain, menjadi 24 jam pelajaran untuk kelas mata pelajaran Bahasa Arab. $^{24}$

Banyaknya jam pelajaran yang ditempuh untuk mata pelajaran PAI dan Bahasa Arab pada kelas mata pelajaran bahasa Arab menjadikan siswa jenuh. Rasa jenuh dan bosan ini menuntut guru untuk mengajar dengan menggunakan metode dan strategi yang variatif. Artinya ketika guru tidak mampu memberikan solusi terhadap rasa jenuh siswa, maka siswa akan mengalami gangguan psikologi yang pada akhirnya memunculkan problem pada kelas ini. Oleh karenanya, setiap guru yang mengajar di kelas ini benar-benar guru pilihan yang memiliki kompetensi dalam berbagai hal termasuk dalam model pembelajaran yang digunakan.

\section{Pembahasan}

Kurikulum merupakan alat untuk mencapai tujuan pendidikan, sekaligus sebagai pedoman dalam pelaksanaan pendidikan. Dalam usaha pencapaian

24 Moch Cholid ,Ketua Program Kelas Mata Pelajaran Bahasa Arab MTs Negeri Sumber Bungur Pamekasan, Wawancara, 15 Mei 2013. 
tujuan pendidikan, peran kurikulum dalam pendidikan formal di sekolah sangatlah strategis. ${ }^{25}$ Bahkan kurikulum memiliki kedudukan dan posisi yang sangat sentral dalam keseluruhan proses pendidikan, serta kurikulum merupakan syarat mutlak dan bagian yang tak terpisahkan dari pendidikan itu sendiri. Mengingat perannya yang cukup strategis, maka ia menjadi tanggung jawab bersama diantara pihak yang terkait (stake holder) dalam proses pendidikan.

Bagi guru, kurikulum berfungsi sebagai pedoman dalam melaksanakan proses belajar mengajar. Bagi kepala sekolah dan pengawas berfungsi sebagai pedoman supervisi atau pengawasan. Bagi orang tua kurikulum itu berfungsi sebagai pedoman untuk memberikan bantuan bagi terselenggaranya proses pendidikan. Sedangkan bagi siswa kurikulum sebagai pedoman pelajaran.

Berkaitan dengan pentingnya pengembangan kurikulum kelas mata pelajaran Bahasa Arab, maka harus diakui bahwa realitas di lapangan saat ini menunjukkan beberapa hal diantaranya adalah:

1) Nilai kemampuan bahasa Arab untuk lulusan MTs dan MA yang masih di bawah standar

2) Hasil ujian masuk PTAI menunjukkan hasil rata-rata peserta tes yang sangat tidak memuaskan, dan

25 Robert Zais, Curriculum, Principles, and Foundation (New York: Harper and Row, 1976), hlm. 104. kalaupun ada peserta yang memiliki talenta kemampuan berbahasa Arab yang baik, mereka adalah yang latar belakang pendidikannya dari pondok pesantren atau lulusan Madrasah Aliyah Program Khusus (MAN-PK)

3) Pelajaran bahasa Arab masih dipandang sebagai momok yang menakutkan bagi sebagian siswa, pelajaran yang begitu linier, menjemukan, memberatkan (karena terlalu dibebani dengan sederet hafalan teks), disikapi dengan defensif, dan yang lebih parah lagi menganggap bahasa Arab sebagai "anak tiri", pelajaran yang tidak penting. Sehingga tak jarang terdapat antipati untuk mengikuti pembelajaran dimaksud.

Berdasarkan paparan di atas, kompleksitas problem pembelajaran bahasa Arab di Indonesia. Harus segera disikapi dan dicarikan solusi secara inten mengingat begitu besarnya signifikansi penguasaan bahasa Arab, terutama bagi seorang muslim.

MTs Negeri Sumber Bungur Pamekasan sebagai salah satu lembaga pendidikan formal yang dipercaya oleh masyarakat, nampaknya ingin menjawab problem tersebut dengan melakukan pengembangan kurikulum pembelajaran Bahasa Arab sebagai upaya penguatan bagi siswa dan siswa kelas Mata Pelajaran Bahasa Arab, yaitu dengan merealisasikan program pengembangan kurikulum bahasa Arab berbasis kelas mata pelajaran yang kemudian diberi istilah kurikulum kelas mata pelajaran 
bahasa Arab. Langkah ini merupakan suatu terobosan yang tidak hanya untuk menjawab priblematika yang terjadi di masyarakat tetapi juga out put yang dihasilkan diharapkan memiliki kemampuan berkomunikasi Bahasa Arab dalam pengertian yang utuh, yaitu kemampuan memahami dan atau menghasilkan teks lisan dan atau tulis yang direalisasikan dalam empat keterampilan berbahasa, yaitu mendengarkan (istima'), berbicara (kalam), membaca (qira'ah) dan menulis (kitabah).

Apa yang dilakukan oleh MTs Negeri Sumber Bungur ini tidak lepas dari pendapat para ahli bahwa macam atau model pengembangan kurikulum ada yang menggunakan pendekatan administratif, ${ }^{26}$ yaitu pendekatan atau prosedur pengembangan kurikulum yang dilakukan oleh suatu tim atau para pejabat tingkat atas sebagai pemilik kebijakan (pengembangan kurikulum dari atas ke bawah), pendekatan grass roots, ${ }^{27}$ yaitu suatu proses pengembangan kurikulum yang diawali dari keinginan yang muncul dari tingkat bawah (sekolah/guru). Keinginan ini biasanya didorong oleh hasil pengalaman yang dirasakan pihak sekolah/guru, di mana kurikulum yang sedang berjalan dirasakan terdapat beberapa masalah atau ketidaksesuaian dengan kebutuhan dan potensi yang

${ }^{26}$ Lihat: Tedjo Narsoyo, Pengembangan Kurikulum Pendidikan (Bandung: Refika Aditama, 2010), hlm. 40.

${ }^{27}$ Lihat: Ibid., hIm. 46. tersedia di lapangan, dan pendekatan sentral de-sentral, yaitu proses pengembangan kurikulum yang menggabungkan kedua pendekatan tersebut. Dengan demikian dalam pendekatan sentral de-sentral antara pemerintah di pusat sebagai pemilik kebijakan bekerjasama dengan pihak di bawah (sekolah, guru dan para stakeholder), sesuai dengan fungsi dan perannya masing-masing, berkolaborasi mengembangkan kurikulum (merancang, melaksanakan, mengontrol) sesuai dengan kebutuhan dan tantangan yang ada di masyarakat.

Dalam konteks ini, MTs. Negeri Sumber Bungur berupaya agar tidak terjebak pada pendekatan dikotomis administratif vis a vis pendekatan grass roots karena pengembangan kurikulum administratif (sentralistik) dan atau grass roots memiliki kelemahan. Diantara kelemahan model administratif adalah:

1) Tidak dapat mengakomodasi seluruh keragaman wilayah suatu negara

2) Pemahaman kurikulum nasional oleh seluruh wilayah tanah air memerlukan waktu yang relatif lama

3) Penerapan kurikulum sentralisasi oleh wilayah yang sangat luas akan menghadapi banyak hambatan dan kemungkinan penyimpangan.

Sedangkan kelemahan model grass roots adalah:

1) Tidak semua guru dan tenaga kependidikan memiliki keahlian atau 
kecakapan dalam mengembangkan kurikulum

2) Kurikulum yang bersifat lokal kemungkinan lulusannya kurang memiliki daya saing secara nasional

3) Desain kurikulum sangat beragam, sehingga berdampak pada kesulitan melakukan pengawasan

4) Perpindahan siswa dari satu sekolah/daerah ke daerah lain akan menimbulkan kesulitan

Pendekatan sentral-desentral sebagai pola yang menggabungkan kedua model (terpusat dan arus bawah), secara teknis masih bisa dilakukan secara bervariasi. Artinya apakah masih lebih banyak muatan ke pusat atau ke bawah, atau mungkin setengahsetengah.

Menurut Kemp, pengembangan kurikulum bisa bervariasi yaitu bisa seluruhnya atau sebagian dikembangkan oleh pusat dan sebagian lagi oleh daerah. Oleh karena itu mengingat pola yang dikembangkan ini menggabungkan keduanya (pusat dan daerah), maka pendekatannya disebut dengan manajmen pengembangan sentral-desentral. ${ }^{28}$

Sebagai wujud pengembangan kurikulum dengan penedekatan sentral desentral di MTs Negeri Sumber Bungur Pamekasan, maka terdapat penambahan jam pelajaran dan materi ajar, yaitu bahasa Arab yang semula 3

28 Kemp, Planning and Producing Instructional Media, Fifth Edition. (New York: Harper \&Row Publisher, 1985) dalam Suplemen Bahasan Ajar Unit 5 Dikti, hlm. 56-57. jam pelajaran menjadi 8 jam pelajaran dan mata pelajaran PAl (Fiqh, Qur'an Hadits, Aqidah Akhlak, dan SKI) dari 2 jam pelajaran menjadi 4 jam pelajaran.

Berdasarkan keterangan di atas, pelaksanaan kurikulum di MTs Negeri Sumber Bungur Pamekasan tidak terpaku pada kurikulum pusat an sich dan juga tidak hanya menggunakan kurikulum lokal, akan tetapi ada integrasi kurikulum nasional dan lokal dengan cara menambahkan materi melalui penambahan jam pelajaran.

\section{Faktor Pendukung dan Penghambat Pelaksanaan Kurikulum Kelas Mata Pelajaran Bahasa Arab MTs Negeri Sumber Bungur Pamekasan}

Dalam proses pengembangan kurikulum kelas mata pelajaran Bahasa Arab, MTs Sumber Bungur memiliki faktor pendukung yang dapat menunjang terlaksananya kurikulum kelas mata pelajaran bahasa Arab dan faktor penghambat yang dapat menghabat terlaksananya kurikulum tersebut.

Diantara faktor pendukungnya adalah pertama, motivasi dari Kantor Wilayah Kementerian Agama Jawa Timur yang telah memberikan inspirasi melalui buku yang berjudul "The Shapping School Culture". Disamping itu, mereka juga berpartisipasi aktif dalam menunjang kebijakan pengembangan kurikulum kelas mata pelajaran Bahasa Arab.

Kedua, komitmen Kepala MTs Negeri Sumber Bungur Pamekasan 
untuk mengembangkan kurikulum dengan sedemikian rupa merupakan modal utama pengembangan kurikulum di MTs Negeri Sumber Bungur Pamekasan. Kepala madrasah merupakan tokoh kunci dalam manajemen madrasah. Kebijakan dan keputusan mengenai berbagai hal ada pada kepala Madrasah. Secara umum, peran dan fungsi kepala madrasah adalah sebagai berikut:

Sebagai manajer, kepala madrasah bertanggung jawab atas manajemen madrasah. Kepala madrasah mengkoordinasikan kegiatan merencanakan, mengorganisasikan, melaksanakan, memimpin, dan mengendalikan segenap usaha pencapaian tujuan pendidikan. Dalam aspek perencanaan, kepala madrasah merupakan pelaku yang selalu terlibat dan bahkan sering menjadi tumpuan dalam kegiatan perencanaan dan pengembangan kurikulum, mulai dari konsep hingga hal-hal yang lebih teknis. Dalam aspek pengorganisasian, kepala madrasah mengorganisasikan unsurunsur, baik unsur manusia maupun unsur non manusia. Unsur-unsur itu diorganisasikan untuk membangun sinergi antar unsur. Dari sinergi tersebut tercipta daya baru dengan kualitas yang lebih bernilai bagi pengembangan kurikulum madrasah. Dalam aspek pelaksanaan, kepala madrasah juga sebagai pelaksana lapangan. la adalah orang yang mengkoordinasikan pengembangan kurikulum, dan sekaligus menjadikan atau menerapkan kuirikulum. Kepala madrasah mengemban tugas memimpin. Dalam hal ini kepala madrasah mengarahkan dan memberi komando. Hal yang mendasar di sini adalah kepala madrasah harus berperan sebagai penanggung jawab atas pengembangan kurikulum madrasah.

Sebagai inovator di madrasah, kepala madrasah harus mampu melahirkan ide-ide baru yang kreatif. Pengembangan kurikulum sering kali bermula dari gagasan kepala madrasah. Mengingat kedudukannya sebagai pihak yang mengemban tanggung jawab atas madrasah yang dipimpinnya, maka pada diri kepala madrasah cenderung muncul dorongan-dorongan untuk terus memajukan madrasah. Karena kewenangan yang dimilikinya, ide-ide barunya menjadi lebih terbuka untuk diimplementasikan. Begitu pula dalam konteks pengembangan kurikulum madrasah ini. Kepala madrasah harus mampu manghadirkan inspirasi dan ide pembaharuan, sehingga program madrasah (kurikulum) yang dijalankan senantiasa actual atau mutakhir.

Sebagai fasilitator, Kepala Madrasah harus bisa memenuhi kebutuhan guru dan siswa dalam kaitannya dengan pengembangan kurikulum. Dalam pengembangan kurikulum, pelaksana teknis pengembangan biasanya tidak langsung oleh kepala madrasah, melainkan oleh tim khusus yang ditunjuk. Namun demikian, kepala madrasah terus melakukan komunikasi dengan tim itu 
dan memfasilitasinya untuk mengatasi berbagai persoalan yang muncul. Kepala madrasah harus membantu mengatasi persoalan, melayani konsultasi tim.

Kesimpulannya adalah bahwa Kepala Madrasah mempunyai kedudukan strategis dalam pengembangan kurikulum. Sebagai pemimpin professional, ia menerjemahkan perubahan masyarakat dan kebudayaan, termasuk generasi muda, ke dalam kurikulum. Dialah tokoh utama yang mendorong guru agar senantiasa melakukan upaya-upaya pengembangan, baik bagi diri guru maupun tugas keguruannya. Karena itu, kepala Madrasah perlu mempunyai latar belakang yang mendalam tentang teori dan praktik kurikulum. Perubahan kurikulum hanya akan berjalan dengan dukungan dan dorongan kepala Madrasah. la dapat membangkitkan atau mematikan perubahan kurikulum di madrasahnya.

Ketiga, kompetensi profesional guru kelas mata pelajaran Bahasa Arab cukup menunjang terlaksananya proses pembelajaran yang ideal. Hal ini dikarenakan peran guru dalam administrasi kurikulum cukup signifikan terutama dalam penyusunan silabus dan RPP.

Keempat, eksistensi pesantren sumber bungur sebagai lembaga yang menguatkan proses pembelajaran siswa dan memberikan pemahaman awal pada siswa tentang materi ajar yang terdapat dalam kurikulum kelas mata pelajaran
Bahasa Arab. Pondok Pesantren adalah lingkungan yang menjadi mitra utama dalam mengembangkan kurikulum. Hal ini dikarenakan muatan kurikulum yang sudah disampaikan sebelumnya, berorientasi pada upaya memaksimalkan materi agama dan Bahasa Arab

Kelima, input siswa yang memiliki pemahaman awal terhadap materi yang akan di sajikan menjadi faktor pendukung karena mereka akan lebih mudah menyerap materi yang lebih banyak dan lebih luas dibandingkan dengan materi yang ada pada kelaskelas yang lain. Dalam hal ini, untuk menjaring siswa yang memiliki kemampuan awal, maka dilakukan seleksi masuk dan ketentuan nilai 75 untuk mata pelajaran PAI dan Bahasa Arab.

Kemudian yang menjadi faktor penghambat pelaksanaan kurikulum kelas mata pelajaran Bahasa Arab adalah:

Pertama, tidak adanya alokasi dana khusus sehingga guru pengajar tidak mendapatkan insentif walaupun memiliki tugas yang lebih. Kemudian pengadaan kelas yang representatif masih menjadi kendala karena minimnya alokasi dana yang disediakan.

Kedua, tidak semua guru memiliki kemampuan yang maksimal dalam melakukan penyusunan kurikulum. Oleh karenanya, madrasah berupaya untuk memberikan fasilitas untuk mendatangkan pakar karena sampai saat ini masih belum ada panduan 
maupun pedoman penyelenggaraan kelas mata pelajaran Bahasa Arab. Di antara kesulitan yang dialami dalam penyusunan kurikulum adalah: bidang cakupan, ${ }^{29}$ relevansi, ${ }^{30}$ keseimbangan, ${ }^{31}$ pengintegrasian, ${ }^{32} \quad$ rangkaian, ${ }^{33}$ kontinuitas, ${ }^{34}$ artikulasi, ${ }^{35}$ dan kemampuan transfer. ${ }^{36}$

${ }^{29}$ Bidang cakupan kurikulum meliputi keluasan topik, pengalaman belajar, aktivitas, pengorganisasian unsur-unsur kurikulum serta hubungan pengintegrasian dan pengorganisasian berbagai unsur-unsur kurikulum tersebut. Dengan kata lain cakupan mengacu pada apa unsurunsur kurikulum, apa pengelolaan dan hubungan peintegrasian unsur-unsur kurikulum.

${ }^{30}$ Relevansi adalah menyangkut kegunaan dan kebermaknaan suatu kurikulum bagi orang, masyarakat, dan bangsa. Artinya bahwa kurikulum perlu dikembangkan agar memiliki kegunaan dan kebermaknaan bagi orang, masyarakat, dan bangsa.

${ }^{31}$ Memenuhi variabel, diantaranya adalah: kurikulum yang berpusan pada siswa, kebutuhan siswa dan kebutuhan masyarakat, pendidikan umum dan pendidikan khusus, luas dan dalamnya kurikulum, domain kognitif, afektif dan psikomotor, pendidikan individual dan masyarakat dII.

${ }^{32}$ Para pengembang kurikulum perlu memperhatikan pemaduan, penggabungan dan penyatuan antar disiplin ilmu. Namun demikian hal ini bukanlah menjadi keharusan, bergantung pada filosofi yang dijadikan pendangan dalam pengembangan kurikulum

${ }^{33}$ Sekuen adalah susunan atau urutan pengelompokkan kegiatan atau langkah-langkah yang dilakukan dalam perencanaan kurikulum. Pengembang kurikulum perlu memperhatikan rangkaian unsur-unsur kurikulum.

${ }^{34}$ Makna kontinuitas adalah pengulangan vertikal, yang kompleks dan canggih dalam upaya meningkatkan hasil belajar. Pengulangan tidak hanya berarti pengulangan konten pembelajaran, namun sebagai pengulangan unsur-unsur kurikulum.

${ }^{35}$ Artikulasi adalah pertautan horisontal atau korelasi antara unsur atau kelompok lintas tingkatan sekolah. Dengan kata lain artikulasi
Ketiga, tidak semua guru memiliki kesiapan untuk mengajar di kelas mata pelajaran Bahasa Arab mengingat adanya persyaratan yang tidak semuanya dimiliki oleh setiap guru, misalnya pernah mengenyam pendidikan di Pesantren.

Keempat, tidak sedikit siswa yang merasa jenuh ketika belajar di kelas mata pelajaran Bahasa Arab. Hal ini dikarenakan banyaknya jam pelajaran yang harus dilewati terutama mata pelajaran Bahasa Arab dan PAI. Sehingga apabila ditotal, pada kelas yang lain hanya 11 jam pelajaran untuk mata pelajaran PAI dan Bahasa Arab menjadi 24 jam pelajaran pada kelas mata pelajaran bahasa Arab.

Secara sederhana, faktor penghambat pelaksanaan kurikulum di sekolah maupun madrasah yang ada di Indonesia adalah:

a) Pada guru : guru kurang berpartisipasi dalam pengembangan kurikulum disebabkan beberapa hal yaitu kurang waktu, kekurang sesuaian pendapat, baik dengan sesama guru maupun kepala sekolah \& administrator karena kemampuan dan pengetahuan guru sendiri

merupakan sekuens unit-unit pembelajaran secara lintas tingkatan

${ }^{36}$ Pengembang kurikulum perlu memperhatikan unsur-unsur yang perlu ditransfer. Untuk itu pengembang kurikulum perlu menentukan tujuan, menyeleksi isi atau materi dan meyeleksi strategi pembelajaran yang mengarah pada pendayagunaan proses transfer secara maksimal 
b) Dari masyarakat : untuk pengembangan kurikulum dibutuhkan dukungan masyarakat, baik dalam pembiayaan maupun dalam memberikan umpan balik terhadap sistem pendidikan ataupun kurikulum yang sedang berjalan. Masyarakat adalah sumber input dari sekolah.

c) Masalah biaya: untuk pengembangan kurikulum apalagi untuk kegiatan eksperimen baik metode isi atau sistem secara keseluruhan membutuhkan biaya yang sering tidak sedikit.

d) Kepala sekolah : dalam hal ini seharusnya kepala sekolah mempunyai latar belakang mendalam tentang teori dan praktek kurikulum. Kepala sekolah merupakan peranan yang penting dalam pengembangna kurikulum.

e) Birokrasi : terdiri dari para inspeksi di Kanwil dan juga orang tua maupun tokoh- tokoh masyarakat. Kepala sekolah dan stafnya tidak dapat bekerja dalam kerangka patokan yang ditetapkan oleh Depdikbud.

\section{Penutup}

1. Kurikulum kelas mata pelajaran Bahasa Arab pada dasarnya mengembangkan kurikulum 2006 dengan menekankan pada aspek kebutuhan masyarakat dan pesantren. MTs Negeri Sumber Bungur mengembangkan kurikulum bahasa Arab berbasis kelas mata pelajaran yang kemudian diistilahkan dengan kurikulum kelas mata pelajaran bahasa Arab. Model pengembangan kurikulum yang digunakan adalah sentral de-sentral, yaitu proses pengembangan kurikulum yang menggabungkan dua pendekatan administratif dan pendekatan grass roots. Pengembangan kurikulum ini dimanifestasikan pada penambahan jam pelajaran dan materi ajar, yaitu pada mata pelajaran PAI dan Bahasa Arab yang semula hanya 11 jam pelajaran menjadi 24 jam pelajaran. Penambahan jam ini digunakan untuk mengkaji ilmu nahwu, shorrof, tafsir, dan kitab klasik lainnya.

2. Di antara faktor pendukungnya adalah: 1) Motivasi dari Kantor Wilayah Kementerian Agama Jawa Timur, 2) Komitmen Kepala MTs Negeri Sumber Bungur Pamekasan untuk mengembangkan kurikulum, 3) Kompetensi profesional guru kelas mata pelajaran Bahasa Arab, 4) Eksistensi pesantren sumber bungur sebagai lembaga yang menguatkan proses pembelajaran, dan 5) Input siswa yang memiliki pemahaman awal terhadap materi yang akan di sajikan. Sedangkan faktor penghambatnya adalah: 1) Tidak adanya alokasi dana khusus, 2) Tidak semua guru memiliki kemampuan yang maksimal dalam melakukan penyusunan kurikulum, 3) Tidak meratanya kemampuan guru untuk mengajar di kelas mata pelajaran Bahasa Arab, dan 4) Tidak sedikit siswa yang merasa jenuh ketika 
belajar di kelas mata pelajaran Bahasa Arab karena banyaknya jam pelajaran yang disajikan.

\section{Daftar Pustaka}

Abd. al-Rahman dan Ahmad Usman, Manahij al-Bahts al-ilm wa turuq al-kitabah, (Beirut: Dar al-Fikr t.t.)

Abdullah Idi, Pengembangan Kurikulum; Teori dan Praktik (Yogyakarta: Ar-Ruzz Media, 2007)

Afandi, A. Khozin, ed., Berpikir Teoritis Merancang Proposal (Surabaya:

Amiroh, Ibrahim Basuni, aL Manhaj wa Anasiruhu (Kairo: Dar al Ma'arif, 1991)

Arif, Saiful, Pengembangan Kurikulum (Pamekasan: STAIN Press, 2010)

Arifin, Imron, ed., Penelitian Kualitatif dalam IImu-IImu Sosial dan keagamaan (Malang: Kalimasahada Press, 1996)

Arikunto, Suharsimi, Prosedur Penelitian Suatu Pendekatan Praktik (Jakarta: Bina Aksara,1989)

Arikunto, Suharsimi, Prosedur Penelitian; Suatu Pendekatan Praktek (Jakarta: Rineka Cipta, 1998)

\section{Pascasarjana IAIN Sunan Ampel Surabaya, 2006)}

Basrowi dan Sukidin, Metode Penelitian Kualitatif Perspektif Mikro (Surabaya: Insan Cendekia, 2002)
Dakir, Perencanaan dan Pengembangan Kurikulum (Jakarta: Rineka Cipta, 2004)

Direktorat Jenderal Pendidikan Islam Kementerian Agama, UndangUndang dan Peraturan Pemerintah RI tentang Pendidikan, (Jakarta: Depag, 2006)

Elliot, Educational Psycology Effective Teaching, Efective Learning (Singapore: Brown and Bencmark Publisher, 1999)

Hadi, Sutrisno, Metodologi Research (Yogyakarta: Andi Offset, 1989)

Hamalik, Oemar, Dasar-dasar Pengembangan Kurikulum (Bandung: PT Remaja Rosdakarya, 2007)

$\begin{array}{lr}\begin{array}{l}\text { Pengembangan } \\ \text { (Bandung: PT. }\end{array} & \begin{array}{r}\text { Manajemen } \\ \text { Kurikulum. }\end{array} \\ \text { Rosdakarya, 2006) } & \text { Remaja }\end{array}$

Ladjid, Hafni, Pengembangan Kurikulum Menuju Kurikulum Berbasis Kompetensi (Jakarta: Quantum Teaching, 2005)

Meleong, Lexy J., Metodologi Penelitian Kualitatif (edisi revisi) (Bandung: Remaja Rosdakarya, 2005)

Muhaimin, Pengembangan Kurikulum Pendidikan Agama Islam di Sekolah, Madrasah dan Perguruan Tinggi (Jakarta: PT. Raja Grafindo Persada, 2005)

Muhammad, Ali Ismail, al Manhaj fi al Lughah al 'Arabiyah (Kairo: Maktabah Wahbah, 1997)

Nasution, S., Metode Penelitian Naturalistik-Kualitatif (Bandung: Tarsito, 1988) 
Pengembangan Kurikulum. (Bandung: PT. Citra Aditya Bakti, 1993)

Narsoyo, Tedjo, Pengembangan Kurikulum Pendidikan (Bandung: Refika Aditama, 2010)

Paterson, Kent D. and Deal, Terrence E., The Shaping School Culture Field Book (San Francisco: Wiley Company, 2002)

Qosim, Mohammad, ed., Pondok Pesantren di Pamekasan; Pertumbuhan dan Perkembangannya (Pamekasan: P3M, 2002)

Royyan, Fikri Hasan, Takhtitu al Manahij al Dirosiyah wa Tadruha (Kuwait: Maktabah al Fallah, 1986)
Sukmadinata, Pengembangan Kurikulum; Teori dan Praktik (Bandung: Remaja Rosdakarya, 2005)

Suparno, Membangun Kompetensi Belajar (Jakarta: Dirjen Dikti Depdiknas, 2001)

Suprayogo, Imam, Tobrini, Metodologi Penelitian Sosial-Agama (Bandung: PT. Remaja Rosdakarya, 2001)

Syarief, A. Hamid, Pengenalan Kurikulum Madrasah dan Sekolah, (Bandung: Citra Umbara, 1995)

Yuwana, Seya, Sudikan, Metode Penelitian Kebudayaan (Surabaya: Universitas Negeri Surabaya Press, 2001) 